\title{
Place attachment and determinants of living arrangement in the family house in Ibadan, Nigeria
}

\author{
Adesina A. Akinjokun ${ }^{1,2}$, Mahmud Bin Mohd Jusan ${ }^{1,3}$ \\ \& Raja Nafida Binti Raja Shahminan ${ }^{3}$ \\ ${ }^{1}$ Department of Architecture, Faculty of Built Environment, Universiti Teknologi Malaysia (UTM),
Johor, Malaysia \\ ${ }^{2}$ Department of Architecture, Faculty of Environmental Design and Management, \\ Obafemi Awolowo University, Ile-Ife, Nigeria. \\ ${ }^{3}$ Centre for the Study of Built Environment in the Malay World (KALAM), Institute for \\ Smart Infrastructure and Innovative Construction (ISIIC), Universiti Teknologi Malaysia.
}

email: sina3x3a@gmail.com; aaakinjokun2@live.utm.my

\begin{abstract}
Context/Background: There is a dearth of study in identifying the determinants of choice of living arrangement in sub-Saharan Africa and what influences individual's decision about this. Therefore, this study examined the physical aspects and demographic characteristics that may be significant predictors of attachment to a particularly form of living arrangement in the form of "family house" otherwise called agbo'le.

Data source and Methods: The analysis was based on quantitative data from 413 household heads in a traditional neighborhood characterized mainly by agbo 'les in Ibadan, Nigeria. Descriptive statistics, chisquare, regression analysis and correlation were used to analyse the data.

Results: The results showed that demographic factors including education attained, occupation and nature of work were significant predictors of place attachment rather than the physical structure.

Conclusion: The study concluded that the relevance of agbo 'le to the lives of the residents and hence its future potentials are more influenced by characteristics of individual residents.
\end{abstract}

Keywords: agbo'le; family house; place attachment; urban housing; Nigeria.

\section{Introduction}

Studies across the world have been able to identify the linkages between living arrangement and health outcome (Weissman \& Russell, 2018; Kimuna, 2005; Hays, 2002). Other studies have been able to link living arrangement to behaviour, including high risk behaviour (Agrawal, 2005). In Africa, living arrangement may have significant influence on social orientation, economic opportunities and other demographic variables (Gabrielli et al., 2018). However, there is a dearth of study in identifying what influences the choice of living arrangement, particularly among traditional non-migrants. This study is particularly focused on a form of traditional arrangement among the Ibadan people in South Western Nigerian popularly referred to as agbo'le.

Literarily, agbo'le is a nomenclature attributed to a form of flock of houses otherwise known as the "family house" or "compound house" in West Africa (Abdul, 2014; Afram \& Korboe 2009; Amole et al, 1993). It evolved in the pre-colonial era out of the culture of the Yoruba people as a form of selfprovision housing occupied in multi-habitation by
Individual households constituting the Yoruba extended family, descended from a common progenitor called "Baba Nla" (Yetunderonke, 2015; Amole et al, 1993). It is a conglomerate of independent or conjoined individual dwelling units with a square enclosing an open space or courtyard in the middle. The individual household dwellings comprise two or more rooms- polygynous or monogamous- and a common wall brings together adjacent units. Traditionally, its design has no provisions for dwelling amenities. Where these are available, they are shared by members of the extended family.

However, since the mid-1900s, changes in people's lifestyle occasioned by modernisation, globalization, and technological progress in the Nigerian society have resulted in the adoption of modern approaches to address housing design issues. Despite this, the patronage of agbo'le has continued among the traditional Ibadan people. Most of these houses are in the context of very challenging environment which are prone to diseases (Adeboyejo \& Onyeonoru, 2005). Yet, people are still attached to 
this and have shown much preference for it. This raises some interesting issues on what are the main attractions and determinants for agbo'le? In other words, the relationship between residents in this context and their home environments represents an important research theme, especially with respect to bonds which people display with respect to places; especially place attachment. Over the years place attachment, reflected as emotional bond between people and their physical environment has been found to inform the way people value their environment and influence their actions (Chen et al, 2014, Manzo \& Devine-Wright 2013; Lewicka, 2011).

Rubinstein \& Parmelee (1992) argued that experiences with a place generally lead to more place attachment. However, the experiences would have to be perceived as positively linked with place attributes (Hernández et al., 2007). Place attachment is indeed a positive phenomenon; it is strongly linked to wellbeing (Theodori, 2001); better social capital (Mesch \& Manor 1998); more satisfaction with life generally, high sense of coherence, less egocentricity, more interest in family roots and stronger neighbourhood ties. In general place attachment has positive social and emotional consequences which are necessary for well-being. Therefore, it is important for housing experts to understand the outcome of individuals and groups experiences that have taken place in a specific place and how that place affects their emotional responses in order to create stable communities. It is also necessary to take advantage of these attachments to place to foster positive community activities which will improve the conditions of these places. In this context of the agbo'le, a study of place attachment will be useful in the sense that rather than suggest relocation of the current population, and demolition of these places, policy experts can leverage on the bonds which people have to the place to foster group participation in the upgrading of the place. Thus, studying attachment to place could be a powerful tool for understanding the family house or the agbo'le and proffering solutions for its improvement.

Place attachment is defined as an affective bond between people and specific places (Low \& Altman, 1992). It has also been defined as a positive affective bond (Hidalgo \& Hernandez, 2001); suggesting that an individual has a tendency to maintain closeness to a place. Other similar concepts to place attachment are neighborhood attachment and community attachment. There are very little differences between these concepts and these differences arise more from the scale at which place attachment is considered.

Place attachment has also been conceptualized in different ways. Most often, place attachment is construed as a concept which comprises two dimensions in the literature; namely place dependence and place identity (Moore \& Graefe,
1994; Williams \& Vaske, 2003; Prayag \& Ryan, 2011). Place dependence, also called functional attachment, describes how important a setting is in facilitating a person's goals and activities (Stokols \& Shumaker, 1981). It usually denotes dependence on the physical attributes of the place. Place identity, on the other hand, refers to the symbolic importance of a place in terms of emotions and relationships which give meaning and purpose to living (Williams and Roggenbuck, 1989). It is also construed as emotional attachment but also with reference to place (William and Vaske, 2003). Other dimensions have however been suggested; namely attachment to people who live in the place (and not just to place, Low and Altman, 1992) and rootedness (Harris et al., 1996). Hidalgo \& Hernandez (2001) have also argued that there is a need to take account of the physical component of the place.

Another important issue which emerges from previous studies is that place attachment may vary with social, physical and environmental characteristics of the place. Consequently, these contextual characteristics and how they are related to place attachment need to be examined. Of particular importance are physical and socio-physical characteristics of places. From the literature, place attachment has two dimensions (Scannell \& Gifford, 2010b): a physical one, which is dedicated to tangible environmental features of a place; and a social/psychological one, which is associated with the intangible or meaningful elements (Hidalgo \& Hernández, 2001; Low \& Altman, 1992). While some authors are of the view that the two dimensions are distinct, others are of the view that the two dimensions are in a symbiotic relationship and consequently, inseparable with respect to place (Burley, 2007). However, the majority of authors assert that the two dimensions should be distinguished and that they play different roles in place attachment (Lewicka, 2011). A review of recent literature however shows that most studies have focused on the social dimensions of place attachment much more than the physical dimensions (Brehm, 2007).

More recently, studies have begun to show the importance of physical or natural environmental characteristics in place attachment. In a study by Brown \& Raymond (2007), the participants gave more value to environmental/physical dimensions such as aesthetics, biological diversity, recreation, and wilderness than to social and economic dimensions of the landscapes being examined. In addition, Scannell \& Gifford, (2010b) found that natural attributes had higher scores than social attributes on an attachment scale. These studies as well as other studies have found that place attachment can be predicted by many physical factors such as quiet areas, aesthetics, presence of green areas, 
(Brown et al., 2003, 2004) housing and neighbourhood quality, access to nature, safety, homeownership, municipal services and neighbourhood density (Fried, 1982). However, there are other physical attributes peculiar to the traditional house (agbo'le) which also need to be examined with respect to place attachment. These include presence of home-based enterprises, household densities; number of bedrooms, activities performed in the agbo'le; facilities and amenities available in the agbo'le and in the neighbourhood.

Existing literature presented juxtaposing evidences between physical structure and individual personal attribute as important determinant of choice of living arrangement. However, there is no clear distinction and congruency on what may influence the choice of such living arrangement among the traditional Ibadan people. This evidence may be important in understanding the nexus between development and housing accommodation in Africa.

\section{Methods}

This research was carried out among the traditional people in Ibadan (see figure 1 for the site and communities) at within a ring at 'Oranyan Community (see figure 2), a compact traditional neighbourhood located within the core of the city of Ibadan, Nigeria. The core of the city of Ibadan is characterized mainly by agbo'les. This makes Ibadan a suitable city in which to study the agbo'le. The courtyard/passage is an essential element of agbo'le. It is also noted as arena for family gathering and socialization, house chores, pen for free-range livestock at night and store for junks. All inhabited houses within the study area were enumerated $(\mathrm{N}=413)$ and adopted for the quantitative survey. Majority of the houses examined comprises of two or more households. However, the household survey was administered on randomly selected one household head or his/her representatives in each of the houses by trained research assistants.

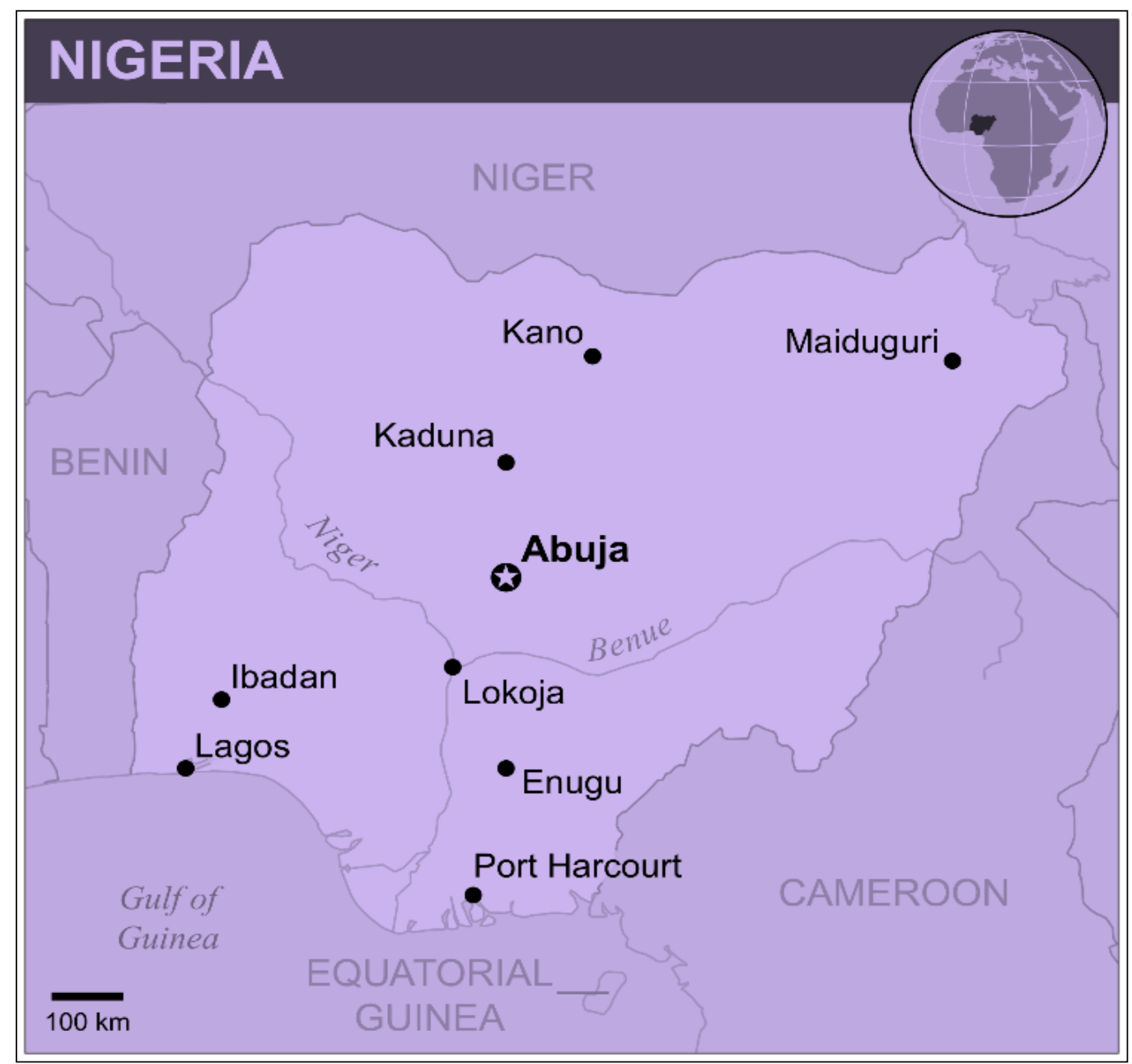

Figure 1: Map of Nigeria showing the location of Ibadan

Source: Nigeria Locator Map (ReliefWeb) (https://reliefweb.int/map/nigeria/nigeria-location-map-2013) 


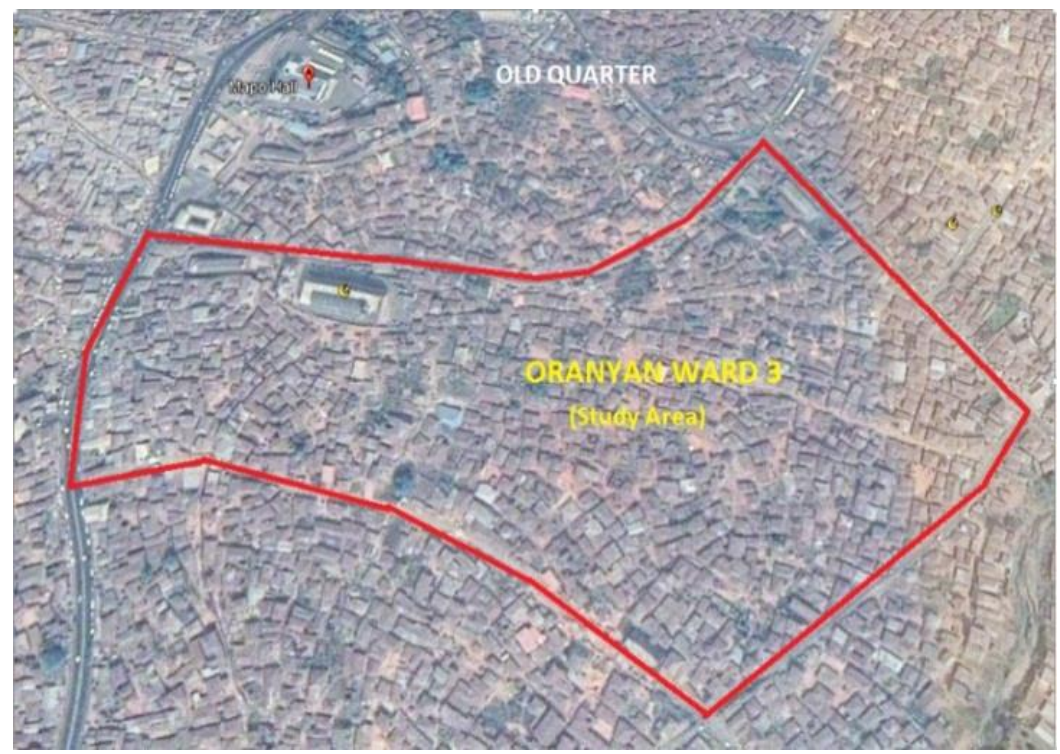

Figure 2: Google map showing boundaries of the study area at "Oranyan" within the core of Ibadan.

First, the quantitative data were analyzed with SPSS using frequencies and percentages. Individual attachment raw scores were considered for the dwelling and the family house separately using all the items which measure place attachment (10 items for the family house and 9 items for the dwelling). The scoring approach adopted is similar to the one employed in a study conducted by Amole, (2014). Overall place attachment scores were computed by summing up individual scores for the household and the family house separately. The overall scores at each of the two levels were sub-divided into five (5) groups and the results are presented in tables $2 \mathrm{~A} \&$ 2B. In addition, the physical characteristics of agbo'le employed as independent variables were cross tabulated against place attachment (dependent variable) at both the dwelling and the family house level to test for association between the two variables.

As suggested by Shrestha (2009), categorical regression was used to identify the predictors of place attachment. First at household level and secondly at family house level. With group attachment score (categorised) and individual attachment raw scores (uncategorised) as independent variables while housing physical characteristics and residents' demographic characteristics constituted the independent variable. Four sets of models of attachment were produced; two for attachment to the dwelling, another two for attachment to the family house. Finally, place attachment to household was correlated against attachment to family house to test if there is any significant difference between the two levels. Non-identifiable photographs were also taken to illustrate some of the findings.

\section{Results}

\section{The household characteristics}

Households' characteristics showed that $47.2 \%$ of the respondents were 60 years old and above. About half http://aps.journals.ac.za of the residents (51\%) were owners of their dwellings, while those in rent-free constituted 9.2\%. Less than one-fifth (18.8\%) rented the accommodation and about $2 \%$ were squatters. Residents' length of stay in the house indicated that $55.8 \%$ of the respondents had lived more than 20 years.

Only about $41 \%$ of respondents had completed primary education while $39.1 \%$ had no education. About $73.3 \%$ were self-employed, $17.3 \%$ worked with the private sector and $1.0 \%$ were employed by the state. Considering the income level of respondents' household, $57.4 \%$ of them earned a combined household income less than N18,000 (equivalent of US\$90.90) per month. Contrary to expectations, the predominant household configuration was the nuclear family and the average number of persons per room is 5.01 .

\section{Dwelling physical characteristics}

Out of the 404 houses/dwellings examined $75.2 \%$ were 60 or more years in age. Majority of the houses $(78.0 \%)$ as indicated in table $1 \mathrm{~A}$ had only one floor while $64.1 \%$ provided accommodation for more than two households. The room constitutes the basic unit of analysis in agbo'le as differentiation or classification of room for specific uses was not common in majority of the households. The highest number of rooms in household dwellings was 17 with a range of 16 rooms while about $38 \%$ of houses had only two rooms.

Measured drawings of the rooms revealed that the average floor area is $(2.4 \times 2.7)$ or $6.48 \mathrm{~m}^{2}$. For the purpose of privacy and good health standards, room floor area in all the agbo'le visited is below the approved minimum standard of $7.0 \mathrm{~m}^{2}$ per person approved by UN Habitat. Moreover, agbo'le occupancy ratio per room at an average of 5.01 persons per room is technically unacceptable. 
Table 1A: Physical characteristics of household's dwelling living spaces

\begin{tabular}{ccc}
\hline Variable & Category & $\%(\mathrm{~N}=404)$ \\
\hline Age of building in years & $30-39$ & 3.7 \\
& $40-49$ & 8.2 \\
Number of floors & $50-59$ & 12.9 \\
& 60 and above & 75.2 \\
Number of rooms & 1 & 78.0 \\
& 2 & 21.8 \\
& 5 & 0.2 \\
Number of rooms & 1 & 33.9 \\
dedicated to sleeping & 2 & 38.6 \\
& 3 & 21.5 \\
& 4 & 3.5 \\
Number of households in a & 5 & 1.5 \\
house & and above & 1.0 \\
& 1 & 33.9 \\
& 2 & 41.8 \\
room & 3 & 21.5 \\
& 4 & 1.7 \\
Number of persons per & 1 & 1.0 \\
& 2 & 7.4 \\
& none & 38.5 \\
& not more than 5 & 20.3
\end{tabular}

Figure 3-6 below present the pictorial evidence of some of the facilities in the agbo'le. These are far below the minimum standard expected for healthy living. There are no toilet facilities in more than half of the buildings and also, there is no source of drinking water within the compound in most of the houses. Almost half of the households did not have designed and dedicated place for cooking, bathroom, toilet and place where to wash and dry clothes within their dwellings (see figures 4 and 5). Table 1B indicated that $51.5 \%$ of the household sampled prepared their food in the passage within their dwellings while a vast number representing $71.8 \%$ had their bathroom made from shacks or a contraption of wood and raffia/discarded corrugated zinc located outside the dwelling. As touching toilet provision, the situation is more worrisome, $74.0 \%$ of the households defecate in the open or inside river Kudeti located at the edge of the community. This is because they did not have a toilet of whatever nature. Majority of the residents $95.3 \%$ (supported by on the spot observation) wash and dry their clothes in open spaces around their dwellings 


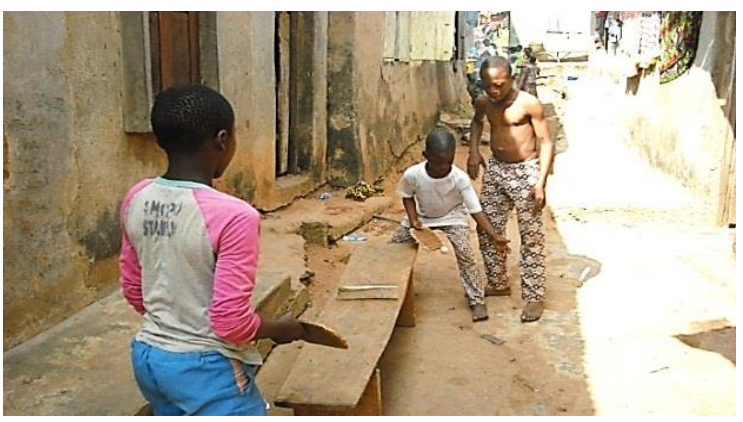

Figure 3: Lack of adequate space for recreation

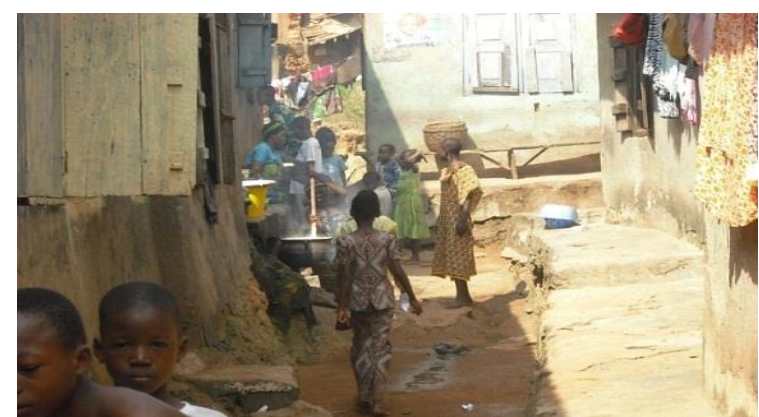

Figure 5: Outdoor cooking within space

between buildings

A greater percentage of the residents (43.1\%) dump their refuse inside river Kudeti. A visual survey of the study site revealed the absence of water stand-pipe. This finding supported respondents' claim to nonavailability of public water. Majority of those sampled, $58.4 \%$ sourced water for general household

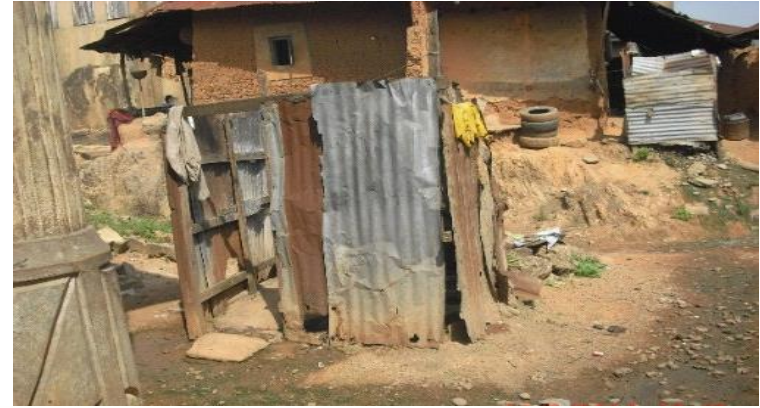

Figure 4: Current condition of most bathroom

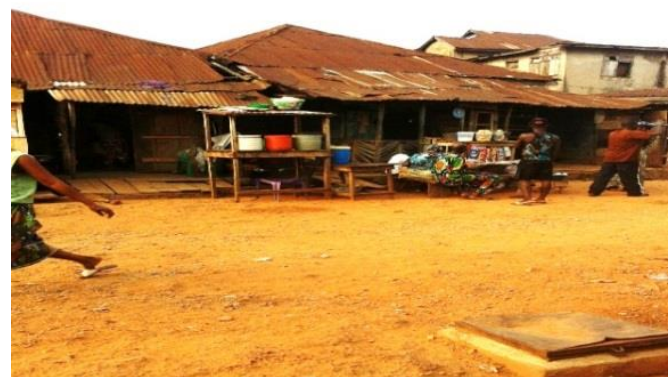

Figure 6: Home based enterprise in front of dwelling

use from covered well while $48.3 \%$ buy drinking water from water merchants. Nearly all $98.8 \%$ of the dwellings were connected to national power gridline and kerosene for $84.2 \%$ of the households constituted primary source of fuel for cooking.

Table 1B: Physical characteristics of household's dwelling amenities

\begin{tabular}{lll}
\hline Variable & category & $\%(\mathrm{~N}=404)$ \\
\hline Place where you cook & Designed \& dedicated space inside dwelling & 17.6 \\
& Designed \& dedicated space outside dwelling & 4.7 \\
& Passage & 51.5 \\
& Temporary shed & 8.4 \\
& Open space outside dwelling & 16.3 \\
Place where you bath & Designed \& dedicated space inside dwelling & 13.6 \\
& Designed \& dedicated space outside dwelling & 12.6 \\
& Temporary shed & 71.8 \\
Place where you defecate & Others & 2.0 \\
& Designed \& dedicated space inside dwelling & 1.0 \\
Place where you wash & Designed \& dedicated space outside dwelling & 25.0 \\
dry clothes & Open space outside dwelling & 74.0 \\
Drinking water & Designed \& dedicated space outside dwelling & 4.7 \\
& Open space outside dwelling & 95.3 \\
Refuse disposal & Covered well/borehole & 25.0 \\
& Public pipe water & 4.2 \\
& Commercial sources (water vendors) & 70.8 \\
& Bush & 11.9 \\
Sewerage disposal & Pit & 42.3 \\
& Incinerator & 2.7 \\
& River Kudeti & 43.1 \\
& Septic tank & 1.0 \\
& Traditional pit/ VIP toilet & 25.0
\end{tabular}




\begin{tabular}{|c|c|c|}
\hline \multirow[t]{2}{*}{ Electricity } & Yes & 98.8 \\
\hline & No & 1.2 \\
\hline \multirow{5}{*}{$\begin{array}{l}\text { Overall physical rating of } \\
\text { dwelling }\end{array}$} & Extremely poor & - \\
\hline & Poor & 9.2 \\
\hline & Fair & 12.4 \\
\hline & Good & 67.8 \\
\hline & Excellent & 10.6 \\
\hline
\end{tabular}

Respondents' rating of the overall physical condition of their dwelling was measured on a 5 point Likert scale; the houses were categorized ranging from extremely poor with a score of (1) to excellent with a score of (5). The categorization was done using 7 criteria. The criteria include, dwelling layout and facilities, spaces between buildings, wall condition, floor condition, roof condition, ceiling condition, condition of water channels and walkways and condition of fittings and fixtures. Statistical analysis showed that $78.4 \%$ of the respondents believed the physical quality of their housing in terms of design and construction was good while $17.0 \%$ agreed it was excellent.

\section{Residents' Attachment to Agbo'le and to their Individual Dwelling Units}

The result of place attachment in the agbo'les was examined and presented as stated below. Tables $2 \mathrm{~A}$ $\& 2 \mathrm{~B}$ show that overall, $74.5 \%$ and $80.9 \%$ of the respondents indicated attachment to their dwellings

Table 2A: Place attachment at the household level

\begin{tabular}{ll}
\hline Attachment scores & Frequency \\
\hline $0-9$ (very unattached) & $1(0.2 \%)$ \\
$10-18$ (unattached) & $20(5.0 \%)$ \\
$19-27$ (indifferent) & $82(20.3 \%)$ \\
$28-36$ (attached) & $193(47.8 \%)$ \\
$37-48$ (very attached) & $108(26.7)$ \\
\hline
\end{tabular}

Table 2B: Place attachment at the family house level

\begin{tabular}{ll}
\hline Attachment scores & Frequency \\
\hline $0-10$ (very unattached) & $0(0 \%)$ \\
$11-20$ (unattached) & $6(1.5 \%)$ \\
$21-30$ (indifferent) & $71(17.6 \%)$ \\
$31-40$ (attached) & $135(33.4 \%)$ \\
$41-50$ (very attached) & $192(47.5 \%)$ \\
\hline
\end{tabular}

and family house respectively. Specifically, $47.5 \%$ expressed very high attachment to their family house while the score for the dwelling was only $26.7 \%$. Moreover, the number of respondents who indicated very strong attachment to the family house is greater than those who expressed same for their dwellings. Consequently, it could be inferred that the residents were more attached to their family house than to their dwellings.

More analysis of the data was carried out using cross-tab to clarify the linear relationship (and the level of significance) between family house physical characteristics (independent variable) and grouped place attachment (dependent variable) measured at two levels "the household" and "family house". The purpose is to examine agbo'le's physical characteristics that predict grouped place attachment within family house level and household dwelling level. From the Chi-square statistics, the calculated Pearson Chi-Square values, p-values, and df are shown below in table 3 . 
Table 3: Chi-Square Test

\begin{tabular}{|c|c|c|c|c|c|c|}
\hline \multirow[t]{2}{*}{ Variable } & \multicolumn{3}{|c|}{ Household dwelling attachment } & \multicolumn{3}{|c|}{ Family house attachment } \\
\hline & value & df & $\begin{array}{c}\text { Asymptotic } \\
\text { significance } \\
\text { (2 sided) }\end{array}$ & Value & df & $\begin{array}{c}\text { Asymptotic } \\
\text { significance } \\
\text { (2 sided) }\end{array}$ \\
\hline $\begin{array}{l}\text { Do you operate a home-based } \\
\text { enterprise? }\end{array}$ & 2.179 & 4 & 0.700 & 3.190 & 3 & 0.363 \\
\hline $\begin{array}{l}\text { Do you share the place where you } \\
\text { wash clothes with others? }\end{array}$ & 4.172 & 4 & 0.383 & 2.475 & 3 & 0.480 \\
\hline $\begin{array}{l}\text { Do you share toilet with other } \\
\text { households? }\end{array}$ & 6.135 & 4 & 0.189 & 3.082 & 3 & 0.379 \\
\hline $\begin{array}{l}\text { Do you share bathroom with other } \\
\text { households?) }\end{array}$ & 8.697 & 4 & 0.069 & 0.809 & 3 & 0.847 \\
\hline $\begin{array}{l}\text { Do you share the place where you } \\
\text { cook with other households? }\end{array}$ & 3.142 & 4 & 0.534 & 1.932 & 3 & 0.587 \\
\hline $\begin{array}{l}\text { Do you share the place where you } \\
\text { eat with other households? }\end{array}$ & 1.941 & 4 & 0.747 & 8.571 & 3 & 0.036 \\
\hline $\begin{array}{l}\text { Number of persons living in } \\
\text { household including yourself }\end{array}$ & 38.024 & 28 & 0.098 & 12.660 & 21 & 0.920 \\
\hline $\begin{array}{l}\text { How many rooms in total are in } \\
\text { your dwelling? }\end{array}$ & 20.919 & 20 & 0.402 & 20.947 & 15 & 0.139 \\
\hline Household density group & 11.086 & 35 & 0.000 & 27.187 & 21 & 0.165 \\
\hline
\end{tabular}

With all the p-values greater than 0.05 , this implies that with respect to household attachment group and family house attachment group, the Pearson Chisquare test is not significant for any of the variables above.

\section{Predicting of place attachment: Correlation between physical factors, residents' demographic characteristics and attachment at household and family house level}

Categorical regression analyses were performed to understand the predictors of place attachment. In the first set of analyses, the dependent variable was the grouped place attachment. Respondent's characteristics (age, marital status, religion, education, level of education completed, occupation, nature of work, combined household monthly income, household current configuration) in addition to the physical characteristics of the family house mentioned in table 3 were the independent variables.
One model each was provided for group place attachment at household level (M1) and family house level (M2). The model presented at household level (M1) was not significant ( $\mathrm{F}=0.895$, df $34, \mathrm{p}=0.640$ $>0.05$ and $\mathrm{R}^{2}=0.120$ ). Only two of the 17 characteristics could predict place attachment. These were respondents' level of education $(\mathrm{F}=3.549, \mathrm{df}=3$, $\mathrm{p}=0.15<0.05)$ and respondents' current household configuration $(\mathrm{F}=6.517, \mathrm{df}=4, \mathrm{p}=0.000)$. On the other hand, the model produced for group place attachment at family house level (M2) was significant $(\mathrm{F}=1.579$, df $32, p=0.026<0.05$ and $\mathrm{R}^{2}=0.120$ ) but the fit between the data and the model was poor. Three of the 17 characteristics could predict place attachment. These were respondents' occupation $(\mathrm{F}=5.517, \mathrm{df}=4$, $\mathrm{p}=0.000<0.05)$, nature of work $(\mathrm{F}=3.945$, $\mathrm{df}=4$, $\mathrm{p}=0.004<0.005)$ and respondents' current household configuration $(\mathrm{F}=8.617, \mathrm{df}=4, \mathrm{p}=0.000)$.

Table 4A: Model summary- dependent variable* physical and residents' characteristics

\begin{tabular}{lcccc}
\hline Model & Multiple R & R Square & $\begin{array}{c}\text { Adjusted R } \\
\text { Square }\end{array}$ & $\begin{array}{c}\text { Apparent } \\
\text { Prediction Error }\end{array}$ \\
\hline M1 & .276 & .076 & -.009 & $.924^{\mathrm{a}}$ \\
M2 & .346 & .120 & .044 & $.880^{\mathrm{b}}$ \\
\hline
\end{tabular}

a. Dependent variable: group place attachment (household level)

b. Dependent variable: group place attachment (family house level)

Table 4B: ANOVA

\begin{tabular}{|c|c|c|c|c|c|}
\hline Model & Sum of Squares & $\mathrm{df}$ & Mean Square & $\mathrm{F}$ & Sig. \\
\hline M1. Regression & 30.784 & 34 & .905 & .895 & $.640^{\mathrm{a}}$ \\
\hline Residual & 373.216 & 369 & 1.011 & & \\
\hline Total & 404.000 & 403 & & & \\
\hline
\end{tabular}




\begin{tabular}{lccccc} 
M2. Regression & 48.419 & 32 & 1.513 & 1.579 & $026^{\mathrm{b}}$ \\
Residual & 355.581 & 371 & .958 & & \\
Total & 404.000 & 403 & & & \\
\hline
\end{tabular}

a. $\quad$ Dependent Variable: group place attachment (household level)

Predictors: Physical characteristics and respondent's demographic characteristics

b. Dependent Variable: group place attachment (family house level)

Predictors: Physical characteristics and respondent's demographic characteristics.

Further analyses were carried out with individual place attachment scores (uncategorized). At the level of the household attachment (M3), the regression model was not significant when all the 17 variables were imputed $(\mathrm{F}=1.069, \mathrm{df}=34, \mathrm{p}=0.368>0.05$ and $\left.\mathrm{R}^{2}=0.090\right)$. The fit between the data and the model was very small. The results showed that there were five characteristics out of 17 that could predict attachment to household (as against two found in group place attachment). These were the respondents' highest level of education $(\mathrm{F}=5.982, \mathrm{df}=2, \mathrm{p}<0.001)$; occupation $(\mathrm{F}=3.147, \mathrm{df}=4, \mathrm{p}<0.015)$, nature of work $(\mathrm{F}=3.396, \mathrm{df}=4, \mathrm{p}<0.010)$, household configuration $(\mathrm{F}=7.711, \mathrm{df}=4, \mathrm{p}<0.000)$, and total number of rooms in respondents' dwelling $(\mathrm{F}=5.239, \mathrm{df}=1, \mathrm{p}<0.023)$.

However, the adjusted (M3*) model was significant when the five (5) predictors were regressed against household attachment scores. The results show that $(\mathrm{F}=1.699, \mathrm{df}=16, \mathrm{p}=0.044<0.05$ and $R^{2}=0.066$ ) but $R^{2}$ was very small. In the adjusted model, the correction for each of the characteristics in the model is as follow: level of education $(\mathrm{F}=6.356$, $\mathrm{df}=3, \quad \mathrm{p}<0.000)$; occupation $\quad(\mathrm{F}=4.795, \quad \mathrm{df}=4$, $\mathrm{p}<0.001)$, nature of work $(\mathrm{F}=3.522, \mathrm{df}=4, \mathrm{p}<0.008)$, household configuration $(\mathrm{F}=8.395, \mathrm{df}=4, \mathrm{p}<0.000)$, total number of rooms in respondent's dwelling $(\mathrm{F}=7.747, \mathrm{df}=1, \mathrm{p}<0.006)$. Therefore, it can be seen that in the prediction of place attachment to household dwelling none of the five characteristics was found to be redundant.
In the next analysis, the same independent variables were regressed against individual attachment scores but at family house level. Overall, the regression model (M4) was not significant $(\mathrm{F}=1.241$, $\mathrm{df}=32$, $\mathrm{p}=0.178>0.05$ and $\left.\mathrm{R}^{2}=0.097\right) . \mathrm{R}^{2}$ was very small and there was also a little fit between the data and the model. The results show that six of the characteristics could predict place attachment. One more variable, respondents' religion $(\mathrm{F}=3.659, \mathrm{df}=2, \mathrm{p}<0.027)$ was added to the five predictors found at household level. These included respondents' highest level of education $(\mathrm{F}=3.285, \mathrm{df}=2, \mathrm{p}<0.039)$; occupation $(\mathrm{F}=6.622, \mathrm{df}=4, \mathrm{p}<0.000)$, nature of work $(\mathrm{F}=3.216$, $\mathrm{df}=4, \mathrm{p}<0.013)$, household configuration $(\mathrm{F}=5.091$, $\mathrm{df}=4, \mathrm{p}<0.001)$, and total number of rooms in respondents' dwelling $(\mathrm{F}=6.508, \mathrm{df}=1, \mathrm{p}<0.011)$.

The adjusted model $(\mathrm{M} 4 *)$ was significant $(\mathrm{F}=1.888$, $\mathrm{df}=17, \mathrm{p}=0.018<0.05)$ but $\mathrm{R}^{2}(0.077)$ was small and still the fit between the data and the model was poor. Two of the characteristics were not very strong predictors of place attachment. These were respondents' level of education $(\mathrm{F}=2.504, \mathrm{df}=2$, $\mathrm{p}=0.83>0.05)$ and religion $(\mathrm{F}=2.396, \mathrm{df}=2, \mathrm{p}=0.92$ $>0.05)$. Respondents' occupation $(\mathrm{F}=5.708, \mathrm{df}=4$, $\mathrm{p}=0.000)$; nature of work $(\mathrm{F}=3.839, \mathrm{df}=4, \mathrm{p}=0.005)$; current household configuration $(\mathrm{F}=4.548, \mathrm{df}=4$, $\mathrm{p}=0.001$ ) and total number of rooms in respondents' dwelling $(\mathrm{F}=5.128, \quad \mathrm{df}=1, \quad \mathrm{p}=0.024)$ were all predictors of attachment. Above all, all the models revealed that other characteristics such as age, sex, sharing of dwelling amenities did not predict place attachment.

Table 5A: Model summary- dependent variable* physical and residents' characteristics

\begin{tabular}{lcccc}
\hline Model & Multiple R & R Square & $\begin{array}{c}\text { Adjusted R } \\
\text { Square }\end{array}$ & $\begin{array}{c}\text { Apparent } \\
\text { Prediction } \\
\text { Error }\end{array}$ \\
\hline M3 & & & & .006 \\
M4 & .299 & .090 & .019 & $.910^{\text {c }}$ \\
M3* & .311 & .097 & .027 & $.934^{\text {e }}$ \\
M4* & .256 & .066 & .036 & $.923^{\mathrm{f}}$ \\
\hline
\end{tabular}

a. Dependent variable: place attachment scores (household level)

b. Dependent variable: place attachment scores (family house level)

c. Dependent variable: place attachment scores (household level)

d. Dependent variable: place attachment scores (family house level) 
Table 5B: ANOVA

\begin{tabular}{|c|c|c|c|c|c|c|}
\hline & Model & Sum of Squares & $\mathrm{df}$ & Mean Square & $\mathrm{F}$ & Sig. \\
\hline \multirow[t]{3}{*}{ M3 } & Regression & 36.234 & 34 & 1.066 & 1.069 & $.368^{\mathrm{c}}$ \\
\hline & Residual & 367.766 & 369 & .997 & & \\
\hline & Total & 404.000 & 403 & & & \\
\hline \multirow[t]{3}{*}{ M4 } & Regression & 39.055 & 32 & 1.220 & 1.241 & $.178^{\mathrm{d}}$ \\
\hline & Residual & 364.945 & 371 & .984 & & \\
\hline & Total & 404.000 & 403 & & & \\
\hline \multirow[t]{3}{*}{ M3* } & Regression & 26.519 & 16 & 1.657 & 1.699 & $.044^{\mathrm{e}}$ \\
\hline & Residual & 377.481 & 387 & .975 & & \\
\hline & Total & 404.000 & 403 & & & \\
\hline \multirow[t]{3}{*}{ M4* } & Regression & 31.014 & 17 & 1.824 & 1.888 & $.018^{\mathrm{f}}$ \\
\hline & Residual & 372.986 & 386 & .966 & & \\
\hline & Total & 404.000 & 403 & & & \\
\hline c. & $\begin{array}{l}\text { Dependent } \\
\text { Predictors: } \mathrm{I}\end{array}$ & $\begin{array}{l}\text { ble: place attachm } \\
\text { cal characteristics }\end{array}$ & $\begin{array}{l}\text { ores (1 } \\
\text { esponc }\end{array}$ & $\begin{array}{l}\text { evel) } \\
\text { graphic charact }\end{array}$ & & \\
\hline \multirow[t]{2}{*}{ d. } & Dependent & ble: place attachm & ores $(1$ & & & \\
\hline & Predictors: I & cal characteristics & esponc & graphic charact & & \\
\hline e. & $\begin{array}{l}\text { Dependent } \\
\text { Predictors: } \mathrm{F}\end{array}$ & $\begin{array}{l}\text { ble: place attachm } \\
\text { cal characteristics }\end{array}$ & $\begin{array}{l}\text { ores }(1 \\
\text { esponc }\end{array}$ & $\begin{array}{l}\text { evel) } \\
\text { graphic charact }\end{array}$ & & \\
\hline f. & $\begin{array}{l}\text { Dependent } \\
\text { Predictors: I }\end{array}$ & $\begin{array}{l}\text { ble: Place attachm } \\
\text { cal characteristics }\end{array}$ & ores ( & $\begin{array}{l}\text { e level) } \\
\text { graphic charact }\end{array}$ & & \\
\hline
\end{tabular}

Table 6A: Coefficients of predictor variables

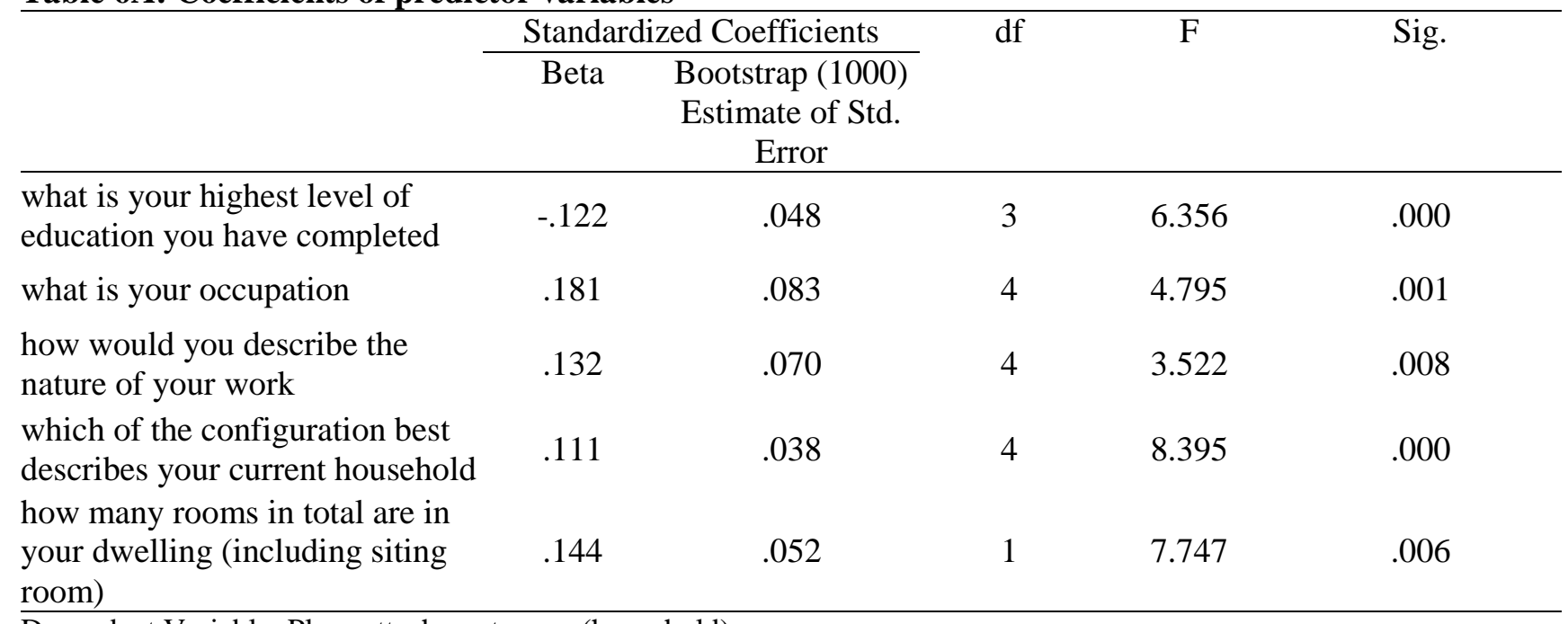

Dependent Variable: Place attachment score (household)

Table 6B: Coefficients of predictor variables

\begin{tabular}{|c|c|c|c|c|c|}
\hline & Stand & lized Coefficients & $\mathrm{df}$ & $\mathrm{F}$ & Sig. \\
\hline & Beta & $\begin{array}{c}\text { Bootstrap (1000) } \\
\text { Estimate of Std. } \\
\text { Error }\end{array}$ & & & \\
\hline $\begin{array}{l}\text { what is your highest level of } \\
\text { education you have completed }\end{array}$ & -.119 & .075 & 2 & 2.504 & .083 \\
\hline what is your occupation & .167 & .070 & 4 & 5.708 & .000 \\
\hline $\begin{array}{l}\text { how would you describe the } \\
\text { nature of your work }\end{array}$ & .110 & .056 & 4 & 3.839 & .005 \\
\hline $\begin{array}{l}\text { which of the configuration best } \\
\text { describes your current } \\
\text { household }\end{array}$ & .089 & .042 & 4 & 4.548 & .001 \\
\hline
\end{tabular}


how many rooms in total are in your dwelling (including siting room)

.139

.075
.062

.048

\section{1}

2
5.128

2.396
.024

.092

Dependent Variable: Place attachment score (family house)

It can be seen from the two tables $6 \mathrm{~A} \& 6 \mathrm{~B}$ above that respondent's level of education has a negative influence on place attachment with scores of -0.122 , \& -0.119 respectively while respondent's occupation recorded the highest positive influence on place attachment with $0.181 \& 0.167$ in that order. In the final model, correlation between household attachment group indicated by the question "how long have you been living in this house?" and family house attachment group designated by the question "how long have you been living in this neighbourhood was done?"

Table 7: Correlation: household dwelling attachment against family house attachment

\begin{tabular}{clll}
\hline & & $\begin{array}{l}\text { Household } \\
\text { attachment }\end{array}$ & $\begin{array}{l}\text { Family } \\
\text { attachment }\end{array}$ \\
\hline \multirow{2}{*}{ Household attachment } & Correlation coefficient & 1.000 & $.649^{* *}$ \\
& Sig. (2-tailed) & & .000 \\
& $\mathrm{~N}$ & 404 & 404 \\
& Correlation coefficient & $.649^{* *}$ & 1.000 \\
Spearman's rho & $\begin{array}{l}0.000 \\
\text { Family house attachment }\end{array}$ & 404 & 404 \\
& Sig. (2-tailed) & & \\
& $\mathrm{N}$ & &
\end{tabular}

** Correlation is significant at the 0.01 level (2-tail).

The result of the crosstab is presented in table 7. The result shows that the two variables are related and with a score of $0.649^{* *}$, there is a strong relationship between them.

\section{Discussion and conclusion}

It is apparent that the residents were permanent residents, owner-occupiers and had been living in the place for a considerable period of time, with several among them remaining in same place for more than 10 years. Consequently, they were very much attached to their household dwelling and family house. This finding is in line with Jiboye \& Ogunshakin, (2010) who found that permanent residents, owner-occupiers express strong preference for the places they occupy and would not like to walk away. In the case of agbo'le residents, this apparent attachment to place is likely to be so because the houses do not only serve as living quarters but also as centre for home-based enterprises, arena for family and festive celebrations as well as ritual grounds. Hence, these houses are important as a home to most of the residents.

According to Okoko, (2001) and Obateru, (2005) the Nigerian government prescribed an index of 2.0 persons per room for the country. Contrary to submissions of previous researchers, (Mayfield, 2011; Kelly \& Hoskings, 2008; Cook, 1988), the context of the study did not have much significant influence on how attached people are to places. There was no significant difference between residents' attachment at household level and at family house level. This is not in agreement with the finding of Kelly \& Hosking, (2008), who compared two townships and found significant differences in both places.

Apart from the difference in place scale in place attachment, the specificity, of place was also found to be an important issue when studying attachment. It could be seen that attachment develops to different degrees in different places. There were differences between the overall attachment to place and to specific levels of the environment. While it was important to understand overall attachment, attachment to specific places differed. Though, the difference in attachment at household level and family house levels was not significantly different, the residents felt more attached to the family house than to their individual dwelling units. This was unexpected as people tend to be attached more to personal than public spaces. This is a divergence from Harris et al., (1996) who found a relationship between place attachment and privacy.

Users' characteristics as well as the characteristics of the place have been suggested as the main predictors of place attachment (Woolever, 1992). The findings of this study indicate that the factors which may explain place attachment are more complex. This fact is supported by previous works (Steadman, 2006; Moore \& Scott, 2003) which examined the predictors of place attachment in different contexts and also by this study. This study found that users' characteristics and the physical context could not all together explain place attachment to the household or family house. 
This suggests that many other factors such as beliefs, participation, social networks, values and goals may be far more important than those used in this study in explaining place attachment. This is also why much of the variance in place attachment (where the model was significant) could be explained by the variables in the model. The explanatory power of the variables was small.

In addition, resident's demographic characteristics such as gender were not found to be a significant predictor of place attachment as found by Hildago \& Hernandez (2001). Hildago \& Harnandez (2001) established that age is correlated to attachment, nevertheless, in this study it was not found to be so. However, level of education, occupation and nature of work were predictors of place attachment. This might be because they are highly correlated with one another; they were all related to economic activities which for majority of the residents is home-bound.

Although the physical aspects of the living arrangement of the households examined in the context of the family house did not provide sufficient evidence of attachment, yet the aspects related to economic opportunities appeared to be good predictors. The implication of this is that in the creation or recreation of new agbo'les, architects, urban designers/planners should never take for granted those aspects related to residents' characteristics that would support their economic activities. Majority of the residents could not be integrated into the public sector because they fall within the group that did not enjoy education at all or those who did not go beyond primary school. Hence, they depend on the available spaces for work-base within their family houses for making daily living/survival.

Therefore, findings from this study suggests, the dependence of the residents on their houses (agbo'le) in fulfilling needs related to economic activities could be a major determinant of their attachment. In addition, it could be the reason why they were more attached to their houses more than to dwellings as some of them have their home-based businesses within the family house (for instance shared spaces, such as locations like courtyard, open spaces, corridors/halls, etc.) but not necessarily within their individual dwellings. This finding is consistent with previous study by Kamalipour et al., (2012) where the significance of the city is related to economic opportunities such as availability of jobs.

As expected from past research, physical and psychological conditions of dwelling, neighbourhood or city affect the significance of each place for inhabitants' attachment. Based on the foregoing, the authors would like to suggest that further studies involving demographic and psychological factors should be carried out so as to clarify the variables that predict attachment to the family house.

\section{References}

Abdul, S. B. O. (2014). "The family as basis of social order: Insights from the Yoruba traditional culture". International Letters of Social and Humanistic Sciences, 23, 79-89

Adeboyejo, T. A. and Onyeonoru, I. P. (2005). "Aspects of home environment and adolescent sexual behaviour in Southwestern Nigeria". African Population Studies, 20 (1)

Adelekan, I. (2016). "Ibadan city diagnostic report". Urban Africa risk knowledge

Afram, S. and Korboe, D. (2009). "Continuity, utility and change: the urban compound house in Ghana". Open House International, Vol. 34, pp.36-46.

Amole, B., Korboe, D. and Tipple, G. (1993). "The family - house in West Africa: A forgotten Resource for policy maker". Third World Planning Review 15/4, p.355

Amole, D. O. (2014). "Place attachment in selected urban and semi-urban students' residences in southwestern Nigeria". Journal of Environmental Design and Management, Vol. 6 (1 \&2), pp.13-28

Brehm, J.M. (2007). "Community attachment: The complexity and consequence of the natural environment facet". Human Ecology, 35 (4), pp.477- 488

Brown, B.B., Perkins, D.D. and Brown, G. (2004). "Incivilities, place attachment and crime: Block and individual effects". Journal of Environmental Psychology, 24(3), pp.359-371

Cook, C.C. (1988). "Components of neighborhood satisfaction: Responses from urban and suburban single-parent women". Environment and Behavior, 20 (2), pp.115-149

Chen, N., Dwyer, L. and Firth, T. (2014). "Effect of dimensions of place attachment on residents' word-of-mouth behavior". Tourism Geographies, 16 (5), pp.826 - 843

Fried, M. (1982). "Residential attachment: Sources of residential and community satisfaction". Journal of Social Issues, 38 (3), pp.107-119

Gabrielli, G., Paterno, A. and Sacco, P. (2018). "Living arrangements in sub-Saharan Africa between modernization and ethnicity". African Population Studies, 32(2), pp.4260-4272

Harris, P.B., Brown, B.B. and Werner, C.M. (1996). "Privacy regulation and place attachment: Predicting attachments to a student family housing facility". Journal of Environmental Psychology, 16(4), pp.287-301

Hays, J.C. (2002). "Living arrangements and health status in later life: a review of recent literature". Public Health Nursing, 19(2):136-151

Hernández, B., Hidalgo, M.C., Salazar-Laplace, M.E. and Hess, S. (2007). "Place attachment and place identity in natives and non-natives". Journal of Environmental Psychology, 27(4), pp.310-319 
Hidalgo, M.C. and Hernandez, B. (2001). "Place attachment: Conceptual and empirical questions". Journal of Environmental Psychology, 21(3), pp. 273-281.

Jiboye, A.D. and Ogunshakin, L. (2010). "The place of the family house in contemporary Oyo town, Nigeria". Journal of Sustainable Development, 3(2), pp. 117

Kabisch, S. and Grossmann, K. (2013). "Challenges for large housing estates in light of population decline and ageing: Results of a long-term survey in East Germany". Habitat International,39, pp.232-239

Kamalipour, H., Yeganeh, A. J., and Alalhesabi, M. (2012). "Predictors of place attachment in urban residential environments: A residential complex case study". Procedia-Social and Behavioral Sciences, 35, pp. 459-467

Kelly, G. and Hosking, K. (2008). "Nonpermanent residents, place attachment, and "sea change" communities". Environment and Behavior, 40(4), pp.575-594

Lewicka, M. (2011). "Place attachment: How far have we come in the last 40 years?" Journal of Environmental Psychology, 31(3), pp.207-230

Low, S.M. and Altman, I. (1992). "Place attachment: A conceptual inquiry". Human Behaviour and Environment: Advances in Theory and Research, pp. 1-12

Mabogunje, A. L. (1962). "The growth of residential districts in Ibadan". Geographical Review, 1: 5677

Manzo, L.C. and Devine-Wright, P. (2013). Place attachment: Advances in theory, methods and applications: Routledge, pp. 1-12

Mayfield, M. (2011). "A place just right: Effects of place attachment on preference for restorative environments".

Mesch, G.S. and Manor, O. (1998). "Social ties, environmental perception, and local attachment". Environment and Behavior, 30(4), pp.504-519

Moore, R.L. and Graefe, A.R.(1994). "Attachments to recreation settings: The case of rail-trail users". Leisure Sciences, 16(1), pp.17-31

Morgan, P. (2010). "Towards a developmental theory of place attachment". Journal of Environmental Psychology, 30(1), pp.11-22

Obateru, O.I. (2005). "Planning regional and rural development". Penthouse Publication, Ibadan, Nigeria.

Okoko, E. (2001). "Residential crowding and privacy in high-density neighbourhoods in Akure, Nigeria”. Ife Social Sciences Review, 19(1), 133144

Prayag, G. and Ryan, C. (2011). "The relationship between the push and pull factors of a tourist destination: The role of nationality-an analytical qualitative research approach". Current Issues in Tourism, 14(2), pp.121-143

Rubinstein, R.I. and Parmelee, P.A. (1992). "Attachment to place and the representation of the life course by the elderly". Place Attachment (pp. 139-163), Springer, Boston, MA.

Scannell, L. and Gifford, R. (2010). "Defining place attachment: A tripartite organizing framework". Journal of Environmental Psychology

Scannell, L. and Gifford, R. (2010b). "The relations between natural and civic place attachment and pro-environmental behavior". Journal of Environmental Psychology, 30(3), pp.289-297

Shrestha, S. L. (2009). "Categorical regression models with optimal scaling for predicting indoor air pollution concentrations inside kitchens in Nepalese households". Nepal Journal of Science and Technology, 10, pp.205-211

Sitawa R. K. (2005). "Living Arrangements and Conditions of Older People in Zimbabwe". African Population Studies, Vol. 20(2)

Stedman, R.C. (2002). "Toward a social psychology of place: Predicting behavior from place-based cognitions, attitude, and identity". Environment and Behavior, 34(5), pp.561-581

Sutapa, A. (2005). "Analyzing Adolescent RiskTaking Behaviour in India: Findings from a large scale survey". Paper presented at the IUSSP XXV International Population Conference Tours, France 18-23 July 2005

Theodori, G.L. (2001). "Examining the effects of community satisfaction and attachment on individual well-being". Rural Sociology, 66(4), pp.618-628

Williams, D., Patterson, M., Roggenbuck, J., and Watson, A. (1992). "Beyond the commodity metaphor: Examining emotional and symbolic attachment to a place". Leisure Sciences, 14, 2946

Weissman, J.D. and Russell D. (2018). "Relationships between Living Arrangements and Health Status among Older Adults in the United States, 2009-2014: Findings from the National Health Interview Survey". J. Appl. Gerontol., 37(1), pp.7-25

Williams, D.R. and Vaske, J.J. (2003). "The measurement of place attachment: Validity and generalizability of a psychometric approach". Forest Science, 49(6), pp.830-840

Woolever, C. (1992). "A contextual approach to neighbourhood attachment". Urban Studies, 29(1), pp.99-116

Yetunderonke, O. (2015). "A study of housing adequacy of multi-habited houses in a typical Nigerian town". International Journal of Advanced and Multidisciplinary Social Science, 1(1), pp.7-12. 
https://commons.wikimedia.org/wiki/File:Nigeria_Location_Map_(2013)_-_NGA_-_UNOCHA.svg
Author/s Guarantee Form: Authors declare that all named authors have contributed sufficiently to the work submitted and that the content of the manuscript has never been previously published.

\section{Appendix}

Survey questions for attachment to household dwelling and family house

\section{Household Dwelling}

How do you agree with the following statements with respect to your dwelling? Please check the box/number that best represents your answer.

\begin{tabular}{|c|c|c|c|c|c|c|}
\hline & & $\begin{array}{l}\text { Strongly } \\
\text { disagree }\end{array}$ & disagree & $\begin{array}{l}\text { Do not } \\
\text { know }\end{array}$ & Agree & $\begin{array}{l}\text { Strongly } \\
\text { agree }\end{array}$ \\
\hline $\mathrm{i}$ & This is an ideal dwelling to live in & 1 & 2 & 3 & 4 & 5 \\
\hline ii & I feel my dwelling is a part of me & 1 & 2 & 3 & 4 & 5 \\
\hline iii & I feel secured in my dwelling & 1 & 2 & 3 & 4 & 5 \\
\hline iv & $\begin{array}{l}\text { I use this dwelling to help define and express } \\
\text { who I am inside }\end{array}$ & 1 & 2 & 3 & 4 & 5 \\
\hline $\mathrm{v}$ & $\begin{array}{l}\text { My dwelling is the best place for doing many } \\
\text { things }\end{array}$ & 1 & 2 & 3 & 4 & 5 \\
\hline vi & $\begin{array}{l}\text { I would not substitute any other area for doing } \\
\text { the type of things I do in my dwelling }\end{array}$ & 1 & 2 & 3 & 4 & 5 \\
\hline viii & I am always glad to return to my dwelling & 1 & 2 & 3 & 4 & 5 \\
\hline ix & $\begin{array}{l}\text { I would feel sorry if I had to move out of my } \\
\text { dwelling }\end{array}$ & 1 & 2 & 3 & 4 & 5 \\
\hline $\mathrm{x}$ & $\begin{array}{l}\text { I would feel sorry if I had to move out of my } \\
\text { dwelling without my neighbours }\end{array}$ & 1 & 2 & 3 & 4 & 5 \\
\hline
\end{tabular}

Family House

How do you agree with the following statements with respect to your family house? Please check the box/number that best represents your answer.

\begin{tabular}{|c|c|c|c|c|c|c|}
\hline & & $\begin{array}{l}\text { Strongly } \\
\text { disagree }\end{array}$ & disagree & $\begin{array}{l}\text { Do not } \\
\text { know }\end{array}$ & Agree & $\begin{array}{l}\text { Strongly } \\
\text { agree }\end{array}$ \\
\hline $\mathrm{i}$ & My family house is an ideal place to live in & 1 & 2 & 3 & 4 & 5 \\
\hline ii & I feel my family house is a part of me & 1 & 2 & 3 & 4 & 5 \\
\hline iii & I feel secured in my family house & 1 & 2 & 3 & 4 & 5 \\
\hline iv & $\begin{array}{l}\text { My family house help to define and express } \\
\text { who I am inside }\end{array}$ & 1 & 2 & 3 & 4 & 5 \\
\hline $\mathrm{v}$ & $\begin{array}{l}\text { My family house is the best place for doing } \\
\text { many things }\end{array}$ & 1 & 2 & 3 & 4 & 5 \\
\hline vi & $\begin{array}{l}\text { I would not substitute any other area for } \\
\text { doing the type of things I do here }\end{array}$ & 1 & 2 & 3 & 4 & 5 \\
\hline vii & $\begin{array}{l}\text { I get more satisfaction from my family } \\
\text { house than from my dwelling }\end{array}$ & 1 & 2 & 3 & 4 & 5 \\
\hline viii & $\begin{array}{l}\text { I am always glad to return to my family } \\
\text { house }\end{array}$ & 1 & 2 & 3 & 4 & 5 \\
\hline ix & $\begin{array}{l}\text { I would feel sorry if I had to move out of } \\
\text { my family house without my neighbours }\end{array}$ & 1 & 2 & 3 & 4 & 5 \\
\hline $\mathrm{x}$ & $\begin{array}{l}\text { I would feel sorry if I and my neighbours } \\
\text { had to move out of my family house }\end{array}$ & 1 & 2 & 3 & 4 & 5 \\
\hline
\end{tabular}




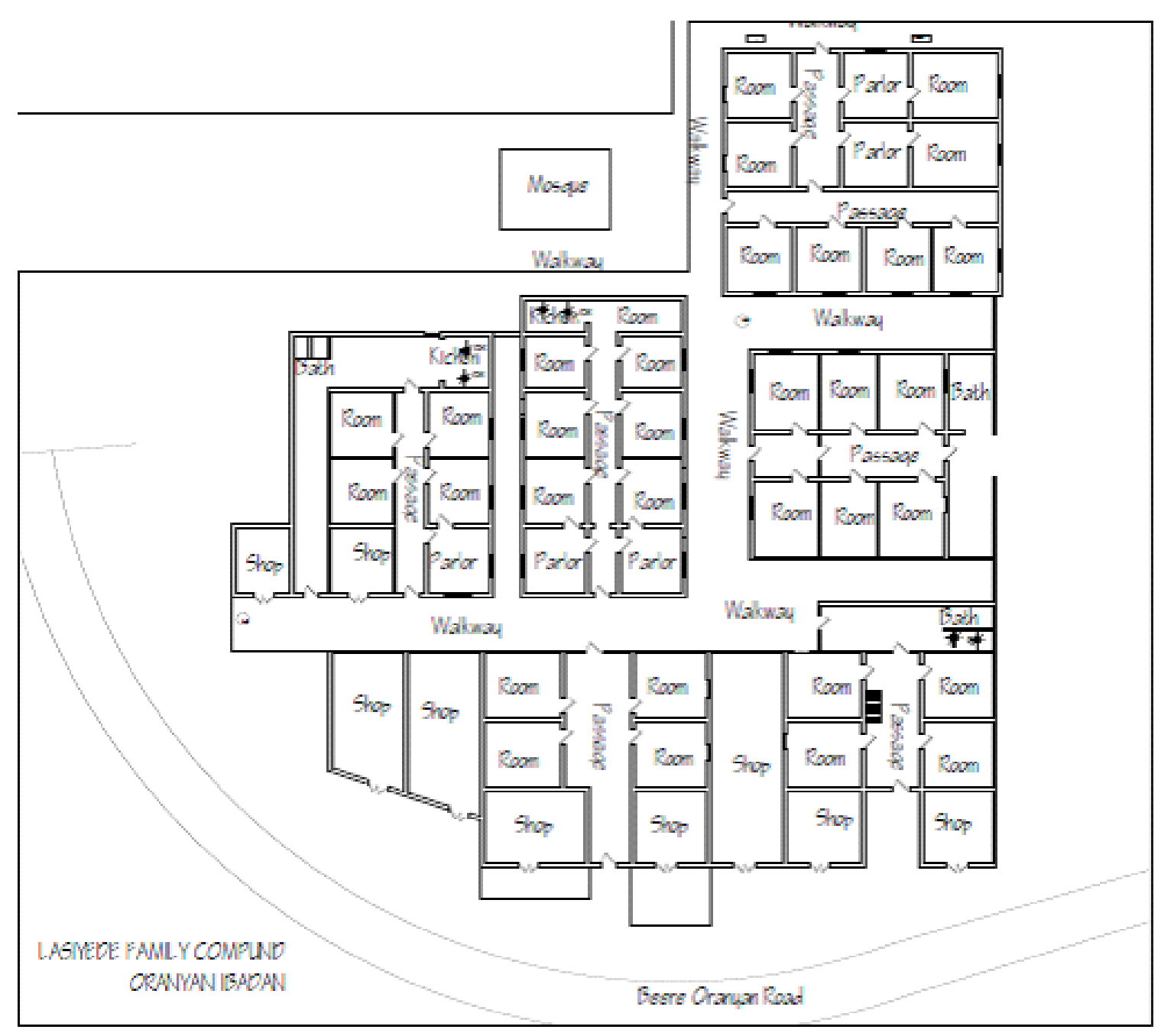

Figure 13: Agbo'le Lasiede (Lasiede Family Compound) 